\title{
DIAGNOSIS DAN PENATALAKSANAAN SIALADENITIS BAKTERI
}

\section{Tinjauan Pustaka}

\author{
Wivan Havilian Djohan', Hanggoro Sapto ${ }^{2}$ \\ ${ }^{1}$ Program Studi Profesi Dokter, Fakultas \\ Kedokteran, Universitas Lampung \\ 2Departemen IImu Penyakit Telinga, Hidung \\ dan Tenggorok, Rumah Sakit Dr. H. Abdoel \\ Moeloek - Fakultas Kedokteran, Universitas \\ Lampung
}

\begin{abstract}
ABSTRAK
Pendahulan: Berbagai penyakit mulai dari obstruksi, infeksi, hingga tumor jinak dan ganas terjadi di kelenjar saliva. Masalah yang paling umum adalah penyumbatan saluran kelenjar saliva yang mencegah drainase air liur.

Metode: Artikel ini dibuat dengan metode literature review, melibatkan 30 referensi baik buku dan jurnal nasional atau internasional.

Pembahasan: Sialadenitis adalah peradangan atau infeksi pada kelenjar saliva yang dapat mempengaruhi kelenjar saliva parotid, submandibular dan yang minor. Sialadenitis dapat disebabkan oleh faktor menular atau tidak menular. Infeksi bakteri atau virus merupakan etiologi yang paling sering. Staphylococcus adalah penyebab bakteri pada umumnya, sedangkan paramyxovirus adalah penyebab virus yang sering. Temuan pencitraan pada kasus ini bervariasi antara pembesaran kelenjar ludah unilateral atau bilateral, atrofi, abses, dilatasi duktus, kista, batu dan kalsifikasi. Pencitraan dapat mendeteksi abses pada sialadenitis supuratif bakteri akut, perubahan duktus dengan kista pada orang dewasa kronis dan parotitis berulang remaja. Korelasi temuan pencitraan dengan presentasi klinis dapat membantu diagnosis sialadenitis. Sialadenitis pasca terapi dapat terjadi setelah pasien dilakukan radioterapi, yodium radioaktif atau operasi.

Simpulan: Diagnosis dan tatalaksana sialadenitis bakteri yang tepat dapat mencegah komplikasi dan prognosis menjadi baik.
\end{abstract}

Kata kunci: abses, inflamasi, kelenjar saliva, sialadenitis, tatalaksana

\section{DIAGNOSIS AND MANAGEMENT OF BACTERIAL SIALADENITIS}

\begin{abstract}
Introduction: Various diseases ranging from obstruction, infection, to benign and malignant tumors occur in the salivary glands. The most common problem is the blockage of the salivary gland ducts which prevents salivary drainage.

Method: This article was created using the literature review method, involving 30 references in both national and international books and journals.

Discussion: Sialadenitis is inflammation or infection of the salivary glands which can affect the parotid, submandibular and minor salivary glands. Sialadenitis can be caused by infectious or non-communicable factors. Bacterial or viral infections are the most frequent etiologies. Staphylococcus is a common cause of bacteria, while paramyxovirus is a
\end{abstract}


frequent cause of viruses. Imaging findings in this case vary between enlarged unilateral or bilateral salivary glands, atrophy, abscesses, ductal dilatation, cysts, stones and calcifications. Imaging can detect abscesses in acute bacterial suppurative sialadenitis, ductal changes with cysts in chronic adults and recurrent adolescent parotitis. The correlation of imaging findings with clinical presentation can help diagnose sialadenitis. Post-therapy sialadenitis can occur after the patient has radiotherapy, radioactive iodine or surgery.

Conclusion: Proper diagnosis and management of bacterial sialadenitis can prevent complications and a good prognosis.

Keywords: abscess, inflammation, management, salivary gland, sialadenitis

\section{PENDAhULUAN}

Air liur (saliva) merupakan campuran kompleks cairan, elektrolit, enzim, dan makromolekul yang berfungsi bersama untuk melakukan beberapa peran penting yaitu, pelumasan untuk membantu menelan dan pencernaan, metabolisme pati dengan amilase pada saliva, modulasi rasa, perlindungan terhadap karies gigi dan pertahanan melawan patogen. Kelenjar saliva mayor adalah kelenjar parotis, submandibular, dan sublingual. Kelenjar saliva minor yang melapisi mukosa bibir, lidah, rongga mulut, dan faring. ${ }^{[1]}$

Penyakit kelenjar saliva utama kadang-kadang ditemukan pada penyakit primer yang terlokalisir. Sialadenitis obstruktif (dari batu atau penyempitan) menyumbang sekitar setengah dari kelainan kelenjar saliva. ${ }^{[2]}$ Neoplasma kelenjar ludah relatif jarang; hanya sekitar $6 \%$ dari semua tumor kepala dan leher, dan insidensi keseluruhannya adalah dua hingga delapan per 100.000 orang di Amerika Serikat. Infeksi dan peradangan kelenjar air saliva memiliki berbagai macam salah satunya sialadenitis. Peradangan dan infeksi kelenjar air liur dapat terjadi kapan saja sejak neonatus dan hingga usia tua. Penyebab infeksi dari sialadenitis yaitu patogen virus dan bakteri. Diagnosis dan manajemen tatalaksana yang tepat dapat menghasilkan prognosis yang lebih baik. ${ }^{[3]}$ Maka dari itu, pada tinjauan pustaka ini penulis akan mempresentasikan diagnosis dan tatalaksana yang tepat untuk sialadenitis akut maupun kronis.

\section{METODE}

Metode dalam penulisan tinjauan pustaka ini yaitu dengan literature review menggunakan literature searching. Kriteria inklusi dalam tinjauan pustaka ini yaitu, jurnal atau buku yang berasal dari tahun 2014 sampai 2020. Hasil literature searching, didapatkan 30 sumber pustaka yang berasal dari Google Scholar, PubMed, MeSH, dan SCOPUS.

\section{PEMBAHASAN}

Kelenjar saliva mayor meliputi kelenjar parotis, submandibular, dan sublingual, sedangkan kelenjar saliva minor tersebar di seluruh rongga mulut dan orofaring termasuk bibir, mukosa bukal, palatum keras dan lunak. Pada orang dewasa, diperkirakan ada 6001000 kelenjar ludah minor. ${ }^{[1,4]}$

Kelenjar air liur memiliki arsitektur yang sama dengan sekelompok sel eksokrin yang terbentuk menjadi asinus dengan saluran sekretori yang mengarahkan saliva ke dalam saluran pengumpul (saluran Stensen untuk parotis, saluran Wharton untuk kelenjar submandibular, dan saluran dari Rivinus untuk kelenjar sublingual)..5] Gambar 1 menggambarkan arsitektur kelenjar saliva.

Kelenjar saliva adalah organ eksokrin yang mengeluarkan campuran bahan serosa atau musin. Diperkirakan 1-1,5 L saliva diproduksi setiap hari. Parotid menghasilkan sekitar 20-25\% dari total air liur harian yang sebagian besar bersifat serosa. Kelenjar submandibular menghasilkan sebagian besar air liur yang tidak distimulasi (70$75 \%$ ) dengan campuran serosa dan campuran mukoid. Kelenjar saliva 


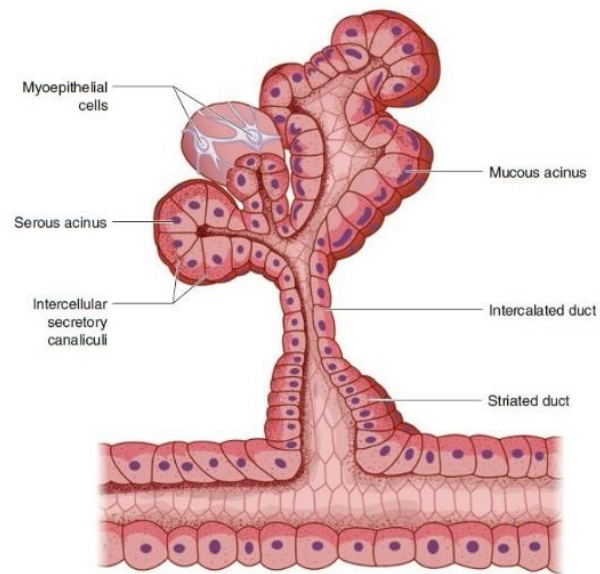

Gambar 1. Struktur kelenjar saliva termasuk asinus, saluran interkalasi dan saluran lurik.[6]

sublingual dan minor mengeluarkan sebagian besar saliva mukoid..5] Sifat biologis air liur memberikan penghalang alami dalam terjadinya infeksi. Komposisi saliva bervariasi tergantung pada berbagai faktor termasuk rangsangan, ritme sirkadian, serta tingkat sekresi dan reabsorpsi senyawa organik dan anorganik. ${ }^{4]}$ Protein saliva termasuk amilase, sistatin, musin, peroksidase, lisozim yang semuanya berfungsi sebagai antimikroba. Ada juga sekresi imunoglobulin termasuk $\lg \mathrm{A}$, dan pada tingkat yang lebih rendah IgG dan IgM. Komponen-komponen ini ditemukan dalam sekresi mukoid. ${ }^{[7]}$ Tidak hanya terdapat sifat antibakteri di saliva, alirannya juga membantu menghilangkan kotoran dan bakteri dari saluran saliva dan mencegah infeksi. ${ }^{[8]}$

Faktor risiko dalam terjadinya infeksi kelenjar saliva meliputi kondisi yang menurunkan aliran saliva serta yang berhubungan dengan imunosupresi (Tabel 1). Infeksi gigi juga meningkatkan risiko infeksi kelenjar saliva. Penularan bakteri dari rongga mulut ke saluran saliva dan kelenjar saliva juga menyebabkan infeksi. ${ }^{[7,8]}$ Penurunan produksi air liur dapat terjadi karena dehidrasi oral. Hal ini dapat terjadi karena output dari penyebab iatrogenik seperti mempuasakan pasien sehingga membuat usus beristirahat atau membatasi asupan air. Kondisi medis lainnya seperti demensia atau gagal
Tabel 1. Faktor risiko terjadinya sialadenitis infeksi[6]

Penurunan produksi air liur

Gangguan autoimun

Sirosis bilier primer

Sarkoidosis

Sindrom Sjogren

Dehidrasi

Penyebab iatrogenik (operasi

perut, istirahat usus, puasa),

lansia, neonatus

Obat-obatan (lihat daftar pada Tabel

2)

Radiasi

Yodium radioaktif

Gagal ginjal

Penurunan aliran air liur

Cystic fibrosis

Striktur duktus

Sialolithiasis

Tumor yang menyebabkan obstruksi duktus

Cedera iatrogenik

Imunosupresi

Infeksi gigi

ginjal dapat menyebabkan pasien mengalami dehidrasi..9]

Selain itu, berbagai obat (Tabel 2)

dapat berefek pada kekeringan rongga mulut dan penurunan aliran saliva. ${ }^{[10,11]}$ Terapi radiasi untuk kanker kepala dan leher sering berefek pada kelenjar saliva. Dosis radiasi sebesar 10-35 Gy ke kelenjar saliva dapat menyebabkan penghancuran asini saliva dengan menghancurkan kelenjar penghasil serosa. ${ }^{[12]} \mathrm{Hal}$ ini dapat dilihat pada pasien yang menjalani pengobatan yodium radioaktif untuk kanker tiroid. Beberapa kondisi autoimun seperti sindrom Sjögren, sarkoidosis, dan sirosis bilier primer juga sering dengan penurunan produksi saliva. ${ }^{[13]}$

Aliran keluar saliva yang menurun biasanya karena obstruksi. Hal ini bisa disebabkan oleh striktur duktal atau sialolithiasis dan juga tumor. Hal ini juga bisa disebabkan oleh cedera iatrogenik pada saluran keluarnya kelenjar. Cystic fibrosis dapat menyebabkan penurunan aliran saliva juga. Imunosupresi meningkatkan risiko sialadenitis bakteri. Selain itu, pasien yang secara aktif 
Tabel 2. Obat-obatan yang memengaruhi produksi dan aliran saliva[ ${ }^{[6]}$

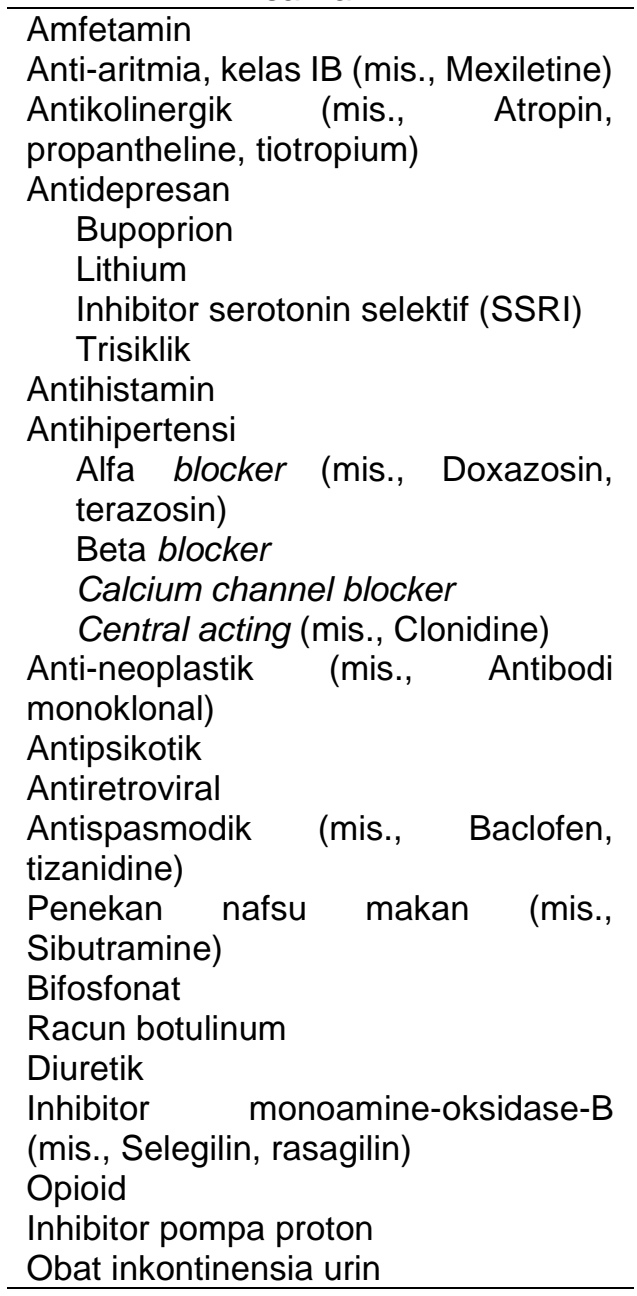

dirawat dengan kemoterapi karena keganasan tidak hanya akan mengalami imunosupresi, tetapi juga dapat dengan mukositis dan odinophagia yang menyebabkan dehidrasi dan kebersihan mulut yang buruk. Diabetes sering menjadi faktor risiko tetapi frekuensi diabetes dalam kejadian sialadenitis bakteri akut tampaknya sama saja jika pasien tanpa diabetes. ${ }^{[2]}$

\section{Sialadenitis Bakteri Akut}

Sialadenitis akut dapat terjadi akibat kontaminasi bakteri flora oral retrograde melalui saluran pengumpul kelenjar saliva. Semua kelenjar dapat terinfeksi, namun kelenjar parotis terinfeksi secara tidak proporsional karena sebagian besar sekresi serous. Sehingga mengakibatkan saliva tidak mengandung antimikroba dan imunoglobulin. Populasi yang lebih sering terkena yaitu orang tua dan pada orang yang tidak cukup terhidrasi. Pasien yang menjalani operasi pada pinggul atau perut lebih berisiko, meskipun risiko keseluruhan pada populasi bedah rendah antara 1 dalam 1000 dan 2000 prosedur. ${ }^{[14]}$

Pasien biasanya mengalami pembengkakan akut dan nyeri tekan yang signifikan pada kelenjar yang terkena; 30\% memiliki eritema pada kelenjar. Pasien mungkin memiliki gejala sistemik termasuk demam, menggigil, dan malaise. Pemeriksaan fisik juga akan sering menunjukkan kehangatan dan indurasi di atas kelenjar yang terkena. Pemeriksaan intraoral biasanya menunjukkan membran mukosa kering. ${ }^{[15]}$ Palpasi bimanual pada kelenjar parotis akan sering menghasilkan sekret yang purulen (Gambar. 2).

Pencitraan dapat dilakukan, meskipun sialadenitis bakteri akut sebagian besar merupakan diagnosis klinis. Sialografi dapat memperburuk peradangan, namun CT atau pencitraan ultrasound dapat dilakukan jika pasien tidak membaik dengan obat-obatan dalam mengevaluasi abses. Jika pada pemeriksaan didapatkan sekret purulensi, sekret dapat dikultur untuk menentukan jenis bakteri dan membantu menentukan antibiotik yang sesuai.[16]

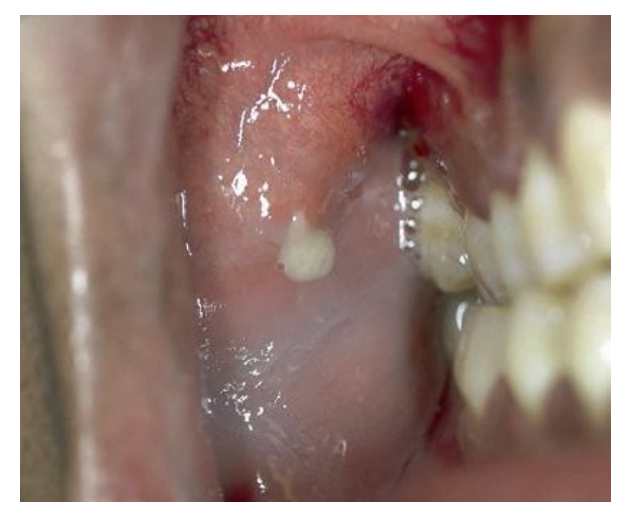

Gambar 2. Pandangan intraoral saluran Stenson (saluran parotis) dengan bukti purulensi pada pijatan parotis. ${ }^{[6]}$ 
Sebagian besar infeksi bakteri akut disebabkan oleh Staphylococcus aureus. Methicillin-resistant S. aureus (MRSA) merupakan patogen yang sering dalam beberapa kasus neonatal. Bakteri anaerob, termasuk Peptostreptococcus, Prevotella, dan Fusobacterium, juga sering pada pasien dengan sialadenitis. ${ }^{[3,17]}$. Di Asia Timur, Klebsiella pneumoniae telah menjadi patogen penting untuk beberapa infeksi (misalnya, abses hati dan endophthalmitis endogen), dan bakteri ini juga telah menjadi penyebab abses parotis dalam populasi di Taiwan. [18]

Penegakkan diagnosis untuk sialadenitis ini terdapat beberapa langkah, yang pertama adalah anamnesis dan periksaan fisik, lalu dilakukan pemeriksaan sesuai tabel 3 . Terapi awal pada sialadenitis akut harus dengan antibiotik spektrum luas yang memiliki cakupan anaerob dan aerob, seperti amoksisilin-klavulanat untuk pasien rawat jalan atau ampicillinsulbactam intravena atau piperacillintazobactam untuk pasien rawat inap. Pada pasien dengan faktor risiko kolonisasi MRSA, biasanya akan dirawat inap jangka panjang sambil menunggu hasil kultur yang sesuai, diterapi dengan vankomisin intravena. ${ }^{[2,19]}$

Pada banyak pasien terdapat penurunan aliran saliva dan berkurangnya produksi. Dengan demikian, langkah-langkah seperti kebersihan mulut yang agresif, hidrasi, dan stimulasi saliva menggunakan sialagogues (misalnya., Permen asam, irisan lemon, jus jeruk) merupakan salah satu terapi.[21] Obatobatan yang dapat membuat membran mukosa kering (Tabel 2) harus dihindari. Aliran saliva juga dapat ditingkatkan dengan menggunakan kompres hangat serta pijat parotis. Pasien atau staf perawat harus diinstruksikan untuk melakukan pijatan dengan tekanan eksternal yang kuat mulai dari sudut mandibula dan menuju komisura oral (untuk kelenjar parotis) atau ke submentum (untuk kelenjar submandibular). Respons positif biasanya terlihat dalam 2-3 hari. ${ }^{[1]}$
Tabel 3. Investigasi diagnosis sialadenitis.[20]

\begin{tabular}{|c|c|}
\hline & Pemeriksaan \\
\hline $\begin{array}{l}\text { Pemeriksaan } \\
\text { Awal }\end{array}$ & $\begin{array}{ll}\text { - } & \text { Kultur dan } \\
\text { sensitivitas } \\
\text { eksudat dari } \\
\text { saluran yang } \\
\text { terinfeksi } \\
\text { Darah } \\
\text { Lengkap } \\
\text { - Radiografi } \\
\text { wajah (oklusal } \\
\text { dan / atau film } \\
\text { jaringan } \\
\text { lunak) }\end{array}$ \\
\hline $\begin{array}{l}\text { Pemeriksaan } \\
\text { yang perlu } \\
\text { dipertimbangka } \\
\text { n }\end{array}$ & $\begin{array}{l}\text { USG kelenjar } \\
\text { yang terkena } \\
\text { - } \quad \text { Computed } \\
\text { tomography } \\
\text { scan } \\
\text { Digital } \\
\text { Subtraction } \\
\text { Angiography } \\
\text { (DSA) } \\
\text { Sialografi } \\
\text { Magnetic } \\
\text { Resonance } \\
\text { (MR) } \\
\text { Sialografi }\end{array}$ \\
\hline $\begin{array}{l}\text { Pemeriksaan } \\
\text { Lanjutan }\end{array}$ & $\begin{array}{l}\text { - Sialoendosco } \\
\text { py }\end{array}$ \\
\hline
\end{tabular}

Dengan terapi yang tepat (termasuk hidrasi), sebagian besar pasien akan membaik dan komplikasi jarang terjadi. Komplikasi dapat mencakup pembentukan abses parotis serta penyebaran infeksi yang menyebabkan septikemia, tromboflebitis, atau osteomielitis. Kelumpuhan wajah jarang terjadi dan biasanya karena terdapat tumor parotid sebelumnya atau keganasan yang menyebabkan obstruksi lalu menyebabkan sialadenitis. Algoritma penatalaksanaan sialadenitis dijelaskan pada tabel 4 .

Mortalitas dengan diagnosis sialadenitis bakteri akut, terutama pada orang tua. Dalam populasi ini, sialadenitis bakteri sering terjadi pada keadaan diperberat dengan komorbiditas multipel yang menurunkan imunitas seluler (misalnya., Kanker), imobilitas 
Tabel 4. Algoritma penatalaksanaan sialadenitis.[20]

\begin{tabular}{ll}
\hline Inisial & Amankan jalan napas \\
kanda-tanda & + Antibiotik spektrum luas \\
& + Cairan intravena
\end{tabular}

Akut

Sialadenitis bakteri Antibiotik intravena spektrum luas atau oral

akut (non obstruktif) + Manajemen konservatif (hidrasi, pereda nyeri, dan sialogogues)

+ Kortikosteroid oral

+ Drainase bedah

Sialadenitis obstruktif Manajemen konservatif (hidrasi, pereda nyeri, dan sialogogues)

+ Pengangkatan batu secara intervensi

Jika dengan infeksi + Antibiotik spektrum luas intravena atau oral

Sialadenitis autoimun Manajemen konservatif (hidrasi, pereda nyeri, dan sialogogues)

+ Pengganti ludah sintetik dan sialogogue

+ Pengobatan kondisi yang mendasarinya

Sialadenitis nekrotikan Observasi

subakut

Kronik

Sialadenitis kronis: Manajemen konservatif (hidrasi, pereda nyeri, dan sialogogues)

berulang atau

sklerosis ( $<3$ kali /

Jika dengan infeksi + Antibiotik spektrum luas intravena atau oral

tahun atau tidak)

Sialadenitis berulang: Eksisi bedah kelenjar yang terkena penyebab apa pun $(>3$

kali/tahun atau

serangan hebat)

(mis., Disfungsi ambulatori atau risiko jatuh), kebersihan mulut yang buruk (mis., Demensia), dehidrasi, dan malnutrisi. Dalam beberapa laporan, mortalitas dapat mendekati $50 \%$, dengan satu seri kasus menunjukkan kematian $80 \%$ di antara pasien yang didiagnosis dengan parotitis bakteri akut, meskipun disertai dengan kondisi medis lainnya. ${ }^{[14]}$ Selain muncul pada orang tua, ada sialadenitis bakteri juga dapat terjadi pada bayi baru lahir, disebut parotitis neonatal akut atau parotitis supuratif neonatal. Infeksi kelenjar submandibular neonatal juga dapat terjadi. Insidensi parotitis supuratif neonatal jarang dan diperkirakan 13,8 per 10.000 neonatus. ${ }^{[22]}$
Sialadenitis Bakteri Kronis Berulang

Sialadenitis kronis biasanya mempengaruhi kelenjar parotis atau biasanya disebut "parotitis kronis". Juvenile recurrent parotitis adalah suatu kondisi etiologi yang tidak diketahui yang biasanya menyerang anak-anak dan ditandai dengan episode berulang dengan pembengkakan dan kemerahan pada satu atau kadang-kadang kedua kelenjar parotis. Pasien mungkin mengalami demam tetapi infeksi biasanya tidak ditemukan. Gejala yang paling umum yaitu adalah pembengkakan, nyeri dan demam. Purulensi dari saluran Stenson tidak terlihat, dan antibiotik tampaknya tidak memiliki peran kecuali dalam kasus superinfeksi.[23,24] Episode dapat berlangsung beberapa hari dan biasanya berulang setiap 3-4 bulan. Hanya 
sebagian kecil pasien yang ditemukan memiliki kondisi reumatologis atau memiliki imunosupresan. Meskipun kekambuhan biasanya sembuh dengan masuk pubertas, episode berulang sebelum itu dapat menyebabkan hilangnya fungsi parotis. Sampai saat ini, tidak ada perawatan yang tampaknya efektif dalam mencegah kekambuhan. Baru-baru ini, sialendoskopi telah digunakan untuk mencegah kekambuhan dan menjadi alat yang menjanjikan prognosis, berdasarkan ulasan literatur dan studi metaanalisis. ${ }^{25,26]}$

Pada pasien dengan parotitis berulang onset dewasa, tanpa obstruksi yang dapat diidentifikasi (mis., Batu, tumor, striktur duktus), upaya yang harus dilakukan adalah untuk mengidentifikasi etiologi bakteri pada setiap episode dan memberikan pengobatan antibiotik yang tepat. Konsultasi dengan ahli reumatologi dan dokter penyakit menular harus dipertimbangkan. Pada pasien yang tidak mengalami obstruksi, biasanya berpengaruh pada kondisi reumatologis sistemik, atau infeksi persisten. Sialendoskopi dapat membantu baik secara diagnostik maupun terapeutik.[23] Jika ini gagal, maka intervensi bedah dapat dianggap sebagai upaya terakhir, memanfaatkan pendekatan parotidektomi total.[27] Pembedahan ini biasanya menjadi tantangan sendiri karena infeksi, peradangan, dan jaringan parut yang sering terjadi. Dalam kasus ini, pasien harus diberitahu tentang risiko akan adanya paresis saraf wajah, yang mungkin bersifat sementara, atau paresis dan kelumpuhan saraf wajah jangka panjang. Demikian pula, intervensi bedah tidak menjamin bahwa semua gejala akan menjadi perbaikan. Jika pembedahan dipertimbangkan dalam tatalaksana sialadenitis bakteri berulang dan kronis, harus dilakukan ketika pasien tidak saat infeksi aktif. Hal ini mungkin memerlukan pretreatment dengan antibiotik dan kemudian pertimbangan perawatan lebih lama pasca operasi.
Abses Kelenjar Saliva
Pada pasien yang gagal menunjukkan perbaikan terapi menggunakan antibiotik dalam waktu 72 jam, harus dipikirkan untuk menjadi abses. Ultrasonografi (Gambar. 3) atau pencitraan CT (Gambar. 4) dapat digunakan untuk mengidentifikasi adanya abses kelenjar saliva. Koalesensi ini muncul sebagai lesi dengan gambaran hipoechoik atau hipodense pada pencitraan. Dalam mengevaluasi pencitraan, penting juga untuk menghilangkan kondisi patologi lain yang mungkin yang dapat memiliki gejala yang serupa seperti keganasan parotis, limfoma, atau abses ruang masticator yang berhubungan dengan karies gigi.

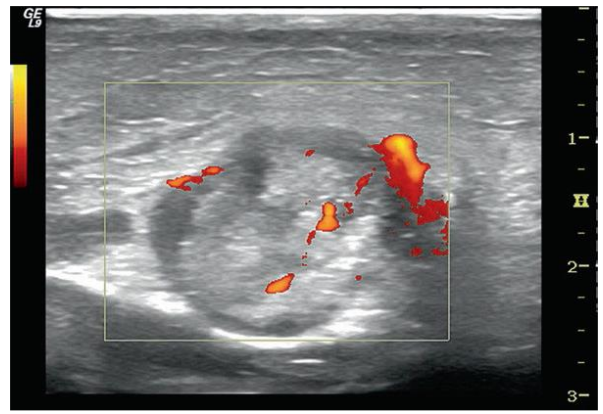

Gambar 3. Pencitraan ultrasonografi menunjukkan abses parotis. ${ }^{[6]}$

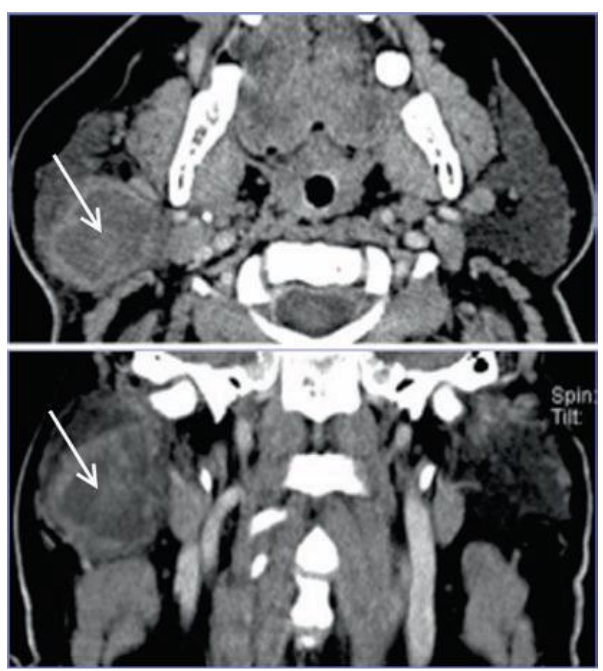

Gambar 4. CT aksial (atas) dan Coronal (bawah) dengan kontras yang menunjukkan area hipodens dengan baik - ditunjuk dengan panah putih. ${ }^{[6]}$ 
Setelah abses kelenjar saliva terjadi, manajemen medis saja tidak akan cukup untuk resolusi. Penatalaksanaan lanjut menggunakan aspirasi jarum bisa di pertimbangkan. Manajemen definitif yang direkomendasikan yaitu drainase bedah. $[28,29]$

Dalam kasus-kasus tertentu, seperti abses dengan volume kecil, abses yang superfisial, non-lokalisir, dan mudah diakses. Dilakukan dibuat sayatan kecil melalui kulit wajah atau leher di lokasi abses dengan mengikuti jalur otot wajah. Kemudian diseksi tumpul, sepanjang arah cabang saraf wajah, dilakukan untuk memasuki rongga abses dengan cara yang paling tidak traumatis untuk mendapatkan drainase dan irigasi rongga abses. Drain pasif dipasang, dilakukan irigasi dan memeriksa rongga abses apakah akan terjadi akumulasi berulang. ${ }^{[30]}$

Pendekatan bedah pada abses parotid sangat mirip dengan yang digunakan untuk parotidektomi untuk pengangkatan tumor jinak atau ganas. Sayatan Blair yang dimodifikasi biasanya sering digunakan. Setelah dilakukan insisi drainasi dan flap, mengairi luka secara menyeluruh dan memastikan drainase lengkap, luka harus ditutup melalui drain pasif yang keluar dari bagian insisi. Pasca operasi, pasien harus melanjutkan antibiotik yang sesuai hasil kultur serta melakukan kebersihan mulut dan hidrasi yang baik.[31]

\section{SIMPULAN}

Sialadenitis bakteri merupakan komplikasi signifikan dari penurunan aliran saliva atau produksinya yang memungkinkan kontaminasi bakteri secara retrograde. Faktor risiko termasuk obstruksi duktus, kondisi medis tertentu, atau obat-obatan yang mengarah ke xerostomia atau dehidrasi, imunosupresi, infeksi gigi, dan usia yang ekstrem (neonatus dan usia lanjut), tetapi beberapa pasien tidak memiliki faktor risiko yang dapat diidentifikasi. Staphylococcus aureus merupakan patogen paling sering menjadi penyebab. Tatalaksana utamanya adalah obatobatan dengan antibiotik dan terapi konservatif (mis. Kompres, pijat, hidrasi) untuk meningkatkan produksi dan aliran saliva. Jarang sekali kasus pasien yang akan berkembang menjadi abses lalu membutuhkan drainase bedah.

\section{DAFTAR PUSTAKA}

1. Kessler AT, Bhatt AA. Review of the Major and Minor Salivary Glands, Part 1: Anatomy, Infectious, and Inflammatory Processes. J Clin Imaging Sci. 2018;8:1-8.

2. Ogle OE. Salivary Gland Diseases. Dent Clin North Am. 2020;64(1):87-104.

3. Wilson KF, Meier JD, Ward PD, City SL. Salivary Gland Disorders. Am Fam Physician. 2014;89(11):882-8.

4. Acharya S. On characteristics of Burning Mouth Syndrome patients. University of Gothenburg; 2018.

5. Xu F, Laguna L, Sarkar A. Agingrelated changes in quantity and quality of saliva: Where do we stand in our understanding? J Texture Stud. 2019;50(1):27-35.

6. Goyal N, Deschler DG. Bacterial Sialadenitis. In: Infections of the Ears, Nose, Throat, and Sinuses. Boston: Springer International Publishing; 2018. p. 291-9.

7. Pedersen AML, Belstrøm D. The role of natural salivary defences in maintaining a healthy oral microbiota. J Dent. 2019;80(July):S3-12.

8. Kubala E, Strzelecka P, Grzegocka M, Lietz-Kijak D, Gronwald H, Skomro P, et al. A Review of Selected Studies That Determine the Physical and Chemical Properties of Saliva in the Field of Dental Treatment. Biomed Res Int. 2018;2018:1-13.

9. Vanholder R, Glorieux G. The intestine and the kidneys: $A$ bad marriage can be hazardous. Clin Kidney J. 2015;8(2):168-79.

10. Wolff A, Joshi RK, Ekstrom J, Aframian D, Pedersen AML, Proctor G, et al. A Guide to Medications Inducing Salivary Gland Dysfunction, Xerostomia, and Subjective Sialorrhea: $A$ Systematic Review Sponsored by 
the World Workshop on Oral Medicine VI. Drugs R D. 2017 Mar;17(1):1-28.

11. Mahdiabadi FM, Nikvarz N. Captopril-induced sialadenitis in a patient with end-stage renal disease. J Res Pharm Pract. 2016;5(2):146-8.

12. Pinna R, Campus G, Cumbo E, Mura I, Milia E. Xerostomia induced by radiotherapy: an overview of the physiopathology, clinical evidence, and management of the oral damage. Ther Clin Risk Manag. 2015 Feb 4;11:171-88.

13. Daniel FI, Lima LD, Grando LJ, Castro R, Cordeiro EAK, Dos Santos CR. Salivary evaluation in radioactive I(131) treated patients with thyroid carcinoma. Acta Odontol Scand. 2018 Mar;76(2):148-52.

14. Coutaz M. Acute bacterial parotitis in the frail elderly subject: a harbinger of death? Vol. 15, Journal of the American Medical Directors Association. United States; 2014. p. 369-70.

15. Stafford JA, Moore CA, Mark JR. Acute sialadenitis associated with 2017-2018 influenza A infection: A case series. Vol. 128, The Laryngoscope. United States; 2018. p. 2500-2.

16. Abdel Razek AAK, Mukherji S. Imaging of sialadenitis. Neuroradiol J. 2017 Jun;30(3):205-15.

17. Poveda-Montoyo I, MartorellLlobregat C, Coy-Coy J, RamosRincon JM. Acute bacterial parotitis due to methicillinresistant Staphylococcus aureus in an institutionalized nonagenarian patient. Vol. 29, Revista espanola de quimioterapia : publicacion oficial de la Sociedad Espanola de Quimioterapia. Spain; 2016. p. 286-7.

18. Chi T, Yuan C, Chen H. Parotid abscess: a retrospective study of 14 cases at a regional hospital in Taiwan. B-ENT. 2014;10:315-8.

19. Troeltzsch M, Pache $C$, Probst
FA, Troeltzsch M, Ehrenfeld M, Otto S. Antibiotic concentrations in saliva: a systematic review of the literature, with clinical implications for the treatment of sialadenitis. J Oral Maxillofac Surg. 2014 Jan;72(1):67-75.

20. Avery C. Sialadenitis. BMJ Best Practice. 2018. p. 1-40.

21. Christou A, Papastavrou E, Merkouris A, Frangos S, Tamana $P$, Charalambous A. Clinical Studies of Nonpharmacological Methods to Minimize Salivary Gland Damage after Radioiodine Therapy of Differentiated Thyroid Carcinoma: Systematic Review. Evidence-Based Complement Altern Med. 2016;2016:1-11.

22. Lindell E, Lundqvist A. Neonatal suppurative parotitis. Vol. 116, Lakartidningen. Sweden; 2019. p. 1.

23. Garavello W, Redaelli M, Galluzzi $\mathrm{F}$, Pignataro L. Juvenile recurrent parotitis: A systematic review of treatment studies. Int $\mathrm{J}$ Pediatr Otorhinolaryngol. 2018 Sep;112:151-7.

24. Singh P, Gupta D. Juvenile Recurrent Parotitis. Vol. 86, Indian journal of pediatrics. India; 2019. p. 749.

25. Ramakrishna J, Strychowsky J, Gupta M, Sommer DD. Sialendoscopy for the management of juvenile recurrent parotitis: a systematic review and meta-analysis. Laryngoscope. 2015 Jun;125(6):1472-9.

26. Papadopoulou-Alataki E, Dogantzis $P$, Chatziavramidis $A$, Alataki S, Karananou P, Chiona $\mathrm{K}$, et al. Juvenile Recurrent Parotitis: The Role of Sialendoscopy. Int J Inflam. 2019;2019:7278907.

27. Roby BB, Mattingly J, Jensen EL, Gao D, Chan KH. Treatment of juvenile recurrent parotitis of childhood: an analysis of effectiveness. JAMA Otolaryngol Head Neck Surg. 2015 Feb;141(2):126-9.

28. Hammett JT, Walker C. Sialolithiasis. Treasure Island 
(FL): StatPearls Publishing; 2020.

$1 \mathrm{p}$.

29. Vaikjarv R, Mandar R, Kasenomm $\mathrm{P}$. Peritonsillar abscess is frequently accompanied by sepsis symptoms. Eur Arch Otorhinolaryngol. 2019 Jun;276(6):1721-5.

30. Kim YY, Lee DH, Yoon TM, Lee JK, Lim SC. Parotid abscess at a single institute in Korea. Medicine (Baltimore). 2018;97(30):1-3.

31. Alam M, Hasan SA, Hashmi SF, Singh PK. Facial Palsy due to Parotid Abscess: An Unusual Complication. Turk Arch Otorhinolaryngol. 2016;54:16871. 